\title{
CULTURAL LANDSCAPE HERITAGE AND THE CONSTRUCTION OF SOCIAL IDENTITY IN THE PRODUCTION AND COMMERCIALIZATION OF WINE IN THE RIBERA DEL RÍO, URUGUAY
}

\author{
ANDER DE LA FUENTE ARANA ${ }^{1}$, URTZI LLANO-CASTRESANA² \& PAULA DURÁN CHAÍN ${ }^{3}$ \\ ${ }^{1}$ Departament of Architecture, University of the Basque Country UPV/EHU, Spain \\ ${ }^{2}$ Faculty of Engineering in Bilbao, University of the Basque Country UPV/EHU, Spain \\ ${ }^{3}$ Faculty of Architecture, Design and Urbanism UDELAR, Uruguay
}

\begin{abstract}
The main aim of the following process is to revitalize a landscape heritage that is of strong character but threatened by oblivion: the landscape of Tannat wine production and marketing, located on the banks of the Uruguay River in the late 19th century. This paper outlines a method to resignify aspects related to its memory. This article focuses on the links regarding the identification and assessment of the resources of the memory, which can be classified into two different areas: traces and narratives. The traces of a landscape represent the tangible settings, which evoke a collective memory. The narratives, which are part of its intangible heritage, are everyday stories that, recalled again and again, make us feel part of that landscape. The planned actions on the studied landscape include, on the one hand, the understanding and revaluation of the traces of memory, such as the Pascual Harriague Winery as a setting for collective memories. On the other hand, we agreed on narratives that give meaning and coherence to the former landscape in this social construct (in this case, the stories of the production and marketing of Tannat wine in Salto, at the end of the 19th century). All this with the purpose of reinforcing the evolutionary capitals of the citizenship identified with the landscape, reaffirming that social group's sense of identity (referential capital) and increasing their resilience or ability to assimilate changes, undertake and innovate. Having analysed the criteria and means to identify and assess the resources of memory, recovering a landscape should be understood as that which implies restoring its image (giving it continuity) and regenerating its social system (reactivating socio-economic dynamics based on the feeling of belonging). None of these is possible without an adequate social participation, which is the engine of the sustainable, socio-economic, local development of this type of landscape. A subjective, non-positivistic approach to the processes is required to achieve our objective: the recovery of the character of a landscape highly determined by socio-economic interrelations.
\end{abstract}

Keywords: image, memory, economic and social landscape, social system.

\section{INTRODUCTION}

The European Convention of Florence (2000) defined the landscape as "any part of the territory, as it is perceived by the population, whose character is the result of the action and the interaction of natural and/or human factors" [1]. Any territory is then an amalgam of landscapes, endowed with a more or less defined "character", depending on, for example, their capacity to become "potential integrators of fragmented heritage" [2].

The purpose of this article is to reflect on how this integration of heritage, which marks the character of a landscape, is capable of generating a sense of identity in its visitors or a sense of anchoring in its inhabitants, so that these can be motivated to reinforce certain socio-economic dynamics with added value. To that end, we propose guidelines to promote initiatives that claim the lost character of a traditional, sustainable, winemaking landscape. 


\section{OBJECT OF ANALYSIS: THE LANDSCAPE OF THE PRODUCTION AND MARKETING OF TANNAT WINE ON THE BANKS OF THE URUGUAY RIVER AT THE END OF THE 19TH CENTURY}

The landscape that matters us represents the footprint of a commercial, industrial and agro-livestock activity that gave impetus to the development of the city of Salto (Fig. 1), in the Oriental Republic of Uruguay at the end of the 19th century. Until the promulgation of the laws of fluvial commerce and the establishment of the Midland railway line that communicated the region with Montevideo since 1884, Salto was station term of the goods that arrived from Rio Grande do Sul (Brazil) to its port. The direct communication with neighbouring Concordia (Argentina) led to the entry of clones of European vines already acclimatized on the banks of Uruguay, giving rise to the viticulture that is in the process of recovery. In 1895, it had more than 85 establishments and a production of 2,215,693 $\mathrm{kg}$ of grapes [3], in addition to the rich fruit crops.

In the late 19th century, we could speak of two rich areas of abundant agricultural production: 'the area that could be called 'urban', which extends from our city and its suburbs to the region of San Antonio, including the latter one, a true colony that tomorrow will form a great industrial town; and the zone that can be called 'rural' and that extends to all the rest of the Department" [5]. The Pascual Harriague Winery (Fig. 2), known as "La Caballada" and integrated in the south of the urban area, has been the most relevant testimony of the birth of the Uruguayan viticulture since 1870. It is considered a figurehead of this historic urban landscape linked to agriculture and industry of agrarian transformation.

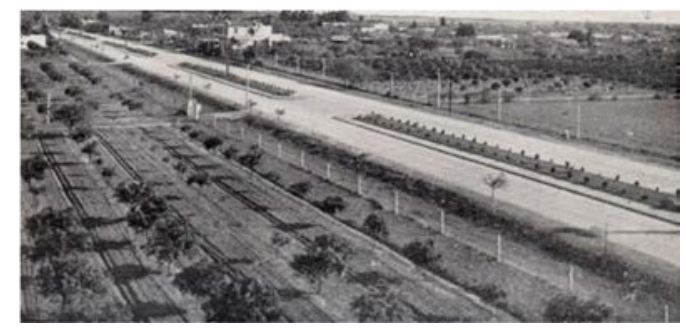

Figure 1: Jose Enrique Rodo Avenue, the "Lineal City" of Salto. The haciendas with the fruit trees and houses of their owners that mark the front towards the boulevard extend towards the periphery in large vineyards. (Source: Villaverde [4].)

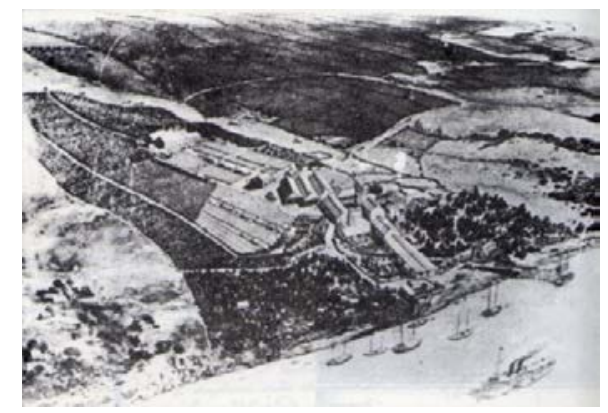

Figure 2: Saladero "La Caballada", with its private port. Inland, the facilities of the Pascual Harriague Winery with its dark-shaded extensions of vineyards around 1885. (Source: Castelli and Grasso [6].) 


\section{OBJECTIVE: SOCIO-ECONOMIC DYNAMIZATION OF AN ECOLOGICALLY SUSTAINABLE LANDSCAPE THROUGH THE RECOVERY OF SALTO'S TRADITIONAL PERI-URBAN WINEMAKING FACILITIES}

Our final objective is the promotion of the recovery of an urban landscape that was ecologically sustainable and economically very profitable, but today has disappeared at the turn of the 19th and 20th centuries. We do not seek to restore the traces of that kind of relationship with the nature of the urbanites of the turn of the century, as if they were archaeological objects. Therefore, it is not only to "value" heritage: we work on "providing social, cultural and economic sense to all heritage activities, not only to those that are directly linked to public access and enjoyment" [7]. The objective is to reinforce the memory of the wine-growing landscape, now converted into heritage to give added value to a sustainable, artisanal way of producing fine wines, which today finds entrepreneurs willing to bet on it.

\section{METHODOLOGY: VALUE CHAIN AND PROCESSES OF RESIGNIFICATION OF THE IDENTITY WITH THE LANDSCAPE}

\subsection{Landscape value chain as an integrator of Cultural Heritage: links}

In the structuring of action projects on landscapes, we rely on the methodology of the Cultural Heritage Value Chain [8], as shown in Fig. 3, to determine the different steps that must be taken in its realization. The links of this "chain" are, basically: the identification; the documentation and registration; the valuation and significance; the intervention; the diffusion and socialization and the impact and reflection.

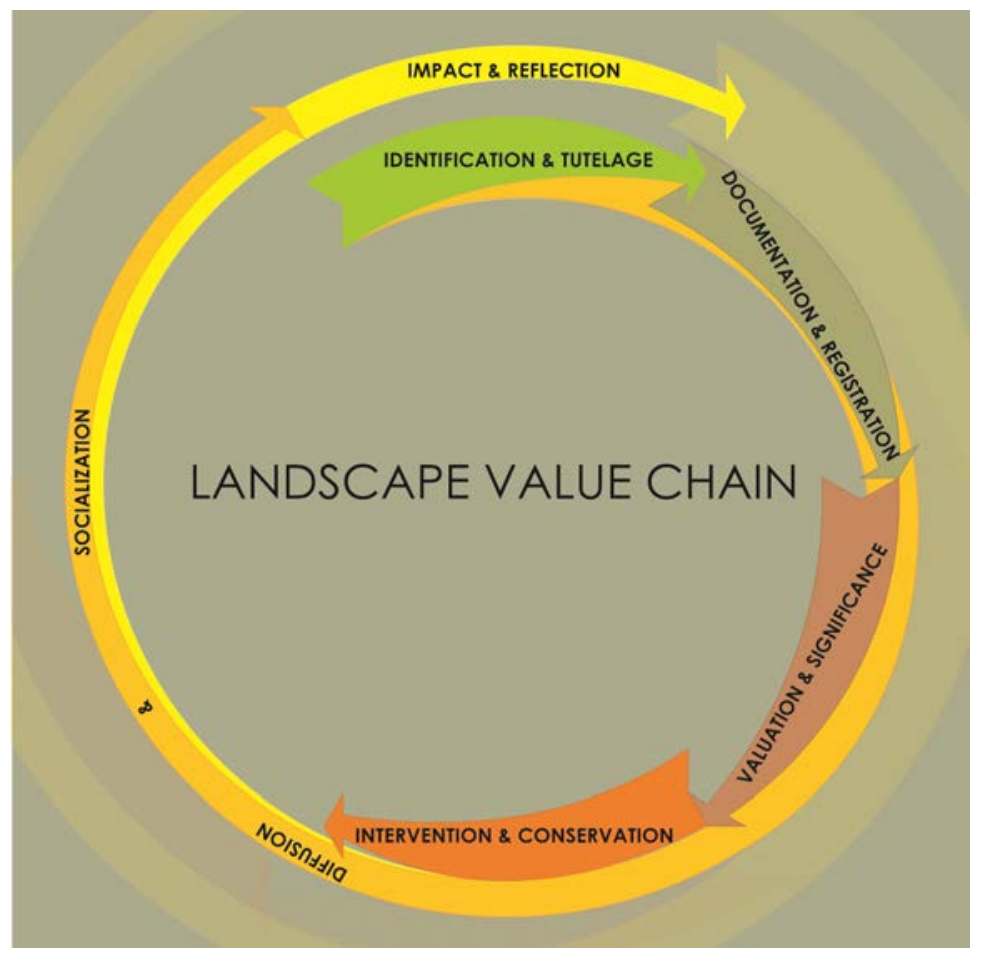

Figure 3: The value chain of cultural heritage. (Source: Own elaboration.) 


\subsection{Landscape identification}

To identify a landscape, we must define both the elements that make it and the objective and subjective interrelationships that give them meaning as part of a system [9].

In fact, the complexity of the identification of a characteristic landscape lies in the fact that the holistic behaviour that gives it meaning must be verified, the parts in which that integral behaviour is structured, the interactions between them and why these finally produce the global functioning of the system [10].

The first step in this identification consists in defining what the holistic behaviour is that we want to highlight in our landscape system. This is translated into the identification of the character of the mentioned landscape and of the social collectives that can potentially feel that character as their own. In this case, we adopt the meaning of the dictionary that defines "character" as "a set of qualities or circumstances of a thing, a person or a community, which distinguishes them from the others by their way of being or acting" [11]. This definition is more in line with the name "character" that the Countryside Commission used to distinguish the different units of landscape or character areas and proceed to their differentiation [12]. From this point of view, our interest would not be so much to classify all the parts of a landscape, but to try to apply a protocol to manage some of them, strategically representative to build a country, and arouse a feeling of "anchorage" in its inhabitants for that "character".

The second process is to define the elements or parts that structure this landscape from the point of view we adopt to characterize it. Those elements can be classified in places [13] or traces of memory (heritage sites) [14]; referents of the image (nodes, milestones, paths, areas, edges) [15], and spaces for direct or indirect collective use for the development of the sociosystem, social ecosystem or socio-ecological system [16]. The third stage of the process is the identification of interrelationships that give meaning to the elements previously defined as parts of a system. It is not enough to catalogue the isolated goods or the spaces that can potentially be integrated into a landscape: we must activate them. This activation of the elements that constitute an identity heritage for the specific social group of the project "implies a process of recognition and valuation that, far from being an automatic or innocent process, generates narratives that, by focusing on certain aspects of heritage, shape the ways in which people relate to their past, evidencing a process of social construction" [17]. In the fourth phase of this identification, the aim is to establish the usefulness of those narratives for the potential that the positive or negative evocation that they arouse has on the feeling of anchoring of the individuals concerned, the quality of life of the inhabitants and, above all, about the desire to preserve and develop the environment they occupy or consider their own.

\subsection{Documentation and landscape registration}

The documentation and registration of the landscape refers to the structuring elements that make it up in its different facets and to the information that concerns the project. It includes the elaboration of bibliography, the generation of archives associated to the project from the testimonies and the documentary emptiness and the planimetry. This information must be selective from its origin, choosing the lines of knowledge that provide data on specific dynamics and resources, with potential interest in resignification.

\subsection{Valuation and meaning of the landscape}

The valuation of the landscape supposes the potential of its resources in function of its visibility, social acceptance and cost of start-up and management. This implies, on the one 
hand, the evaluation of the footprints in terms of "spatial, structural, constructive, functional and even significant qualities, in relation to their condition as constructed matter associated with historical memory, that force to intervene on them with more complex criteria than those managed for a conventional public space project" [18]. On the other hand, it represents a critical act of selection of narratives according to the capacity they have to generate identity.

Regarding the image, the evaluation of its elements will have a very significant basis in the mental maps in which they appear as references of inhabitants or visitors.

Finally, from the point of view of the sociosystem, it is evident the difficulty to "systematically relate interpersonal phenomena with ecological processes, with value systems and with diverse dialectic macrostructural forces, often vaguely conceived" [19]. That is why we propose to adopt and adapt the value and capital system of Carrillo [20]. To do this, it will be necessary to delimit the three areas that, in our opinion, structure this ecosystem, according to the features that differentiate them in each case: the habitat, characterized by natural values; the inhabitants, marked by artificial values, and their habits, defined by their evolutionary values.

\subsection{Intervention on the landscape}

We must design a strategic intervention on potential resources and for the conservation of structuring elements at risk. Despite our tendency towards immediate and colourful intervention, "it is not a question of building new milestones, but of achieving a fine tuning of the evocative elements that this space already possesses" [21].

\subsection{Diffusion and socialization of the landscape}

In its double aspect of social dialogue with the agents involved and dissemination of results, socialization must be a process that underlies all the others, always seeking consensus in decision-making. We must take care of the channels of dissemination of the knowledge acquired and dissemination, through social dialogue or, in scientific fields, through transfer of what has been done in the project.

\subsection{Impact and reflection on landscape}

Although it is a step that is often not considered already included in the process, in all our initiatives we must undertake a reflection on the results and a critical analysis of the processes, establishing in these coefficients of follow-up.

\section{RESULT: PROCESSES OF IDENTITY REINFORCEMENT FOR NEW SUSTAINABLE SOCIOECONOMIC INITIATIVES}

We will analyse the results obtained in our case study, following the steps previously defined to undertake the actions on the landscape of the production and marketing of Tannat wine on the banks of the Uruguay River at the end of the 19th century.

\subsection{Identification of the landscape}

The identification of the landscape that matters us goes through the definition of the character that we intend to reinforce in it. That is its quality of traditional landscape, productive (winegrowing), riparian, and differentiated from other similar ones. This difference is the result of the work of the Basque entrepreneurs who, at the end of the 19th century, left their mark on the extensive vine and fruit plantations, and on the constructions that served 
as support to their elaboration or commercialization, as well as a living environment for their inhabitants.

In this sense, we have proceeded to select the constructed patrimonial traces that evoke the memory of the work of those pioneers. The main memory traces consist of both the haciendas and vineyards now in disuse and the built spaces of the Pascual Harriague Winery. The identification of possible useful aspects to reinforce a sense of identity with the analysed landscape (which fosters future dynamics of social innovation and micro-entrepreneurship) makes us look at both the natural capitals of their habitat and the artificial ones linked with its cultural dynamism (strong Basque presence channelled by the Basque Group of Salto) and economic (active contribution of the local winemakers) or its local governance (decisive involvement of the Intendencia de Salto through its Directorate of Culture). Regarding the evolutionary capitals, we perceive a positive tolerance to innovation and predisposition to change and improvement through the reinforcement of the identity of the community with its winegrowing heritage.

However, all these structuring factors of a specific landscape must be activated by a narrative that gives them meaning to function as a system. The lines of argument that are initially taken into account are about the production and sale of wines with techniques imported from the Basque Country (in connection with Basque initiatives such as Rioja Alavesa intangible heritage). Unfortunately, these techniques have already been lost in our country. It has been noted that the aspects related to the winemaking tradition introduced by the Basque pioneers evoke a strong sense of belonging in many people from Salta, injured even by the cornering to which, according to them, they have been subjected with respect to other areas of Tannat wine production (for them Harriague) from the rest of the country.

\subsection{Documentation and landscape registration}

In this first phase we have worked with the documentation and registration of the basic resources referring to the narratives identified in the previous step. For this purpose, we have analysed the bibliography concerning this part of the history of Salto, working closely with the Museum of Man and Technology. But we have also recovered the daily stories of those who came to know the old salinas wineries in operation and/ or their facilities and footprints in a much more readable state than the current one. The latter has been registered by UDELAR researchers, who have carried out detailed surveys of Harriague Winery spaces. The testimonies about the disappeared have been recorded in interviews with citizens who knew the reality of the pioneer wine landscape of Salto, such as the former employees of the Gramond (an installation that succeeded the wineries in their same location), or those who have investigated it thoroughly.

\subsection{Valuation and meaning of the landscape}

By analysing the different options (Fig. 4), it has been concluded that the spaces with the most potential in terms of visibility, ease of implementation and cost of adaptation are those of Pascual Harriague's own wineries.

From the point of view of memory, this property offers a great variety of traces susceptible of being easily put in value. It has been considered that, among them, the one that has been maintained with less alterations and can constitute an area of attachment for the inhabitants of the neighbouring Saladero neighbourhood and, by extension, of the entire city, is the building known as the Soil Laboratory (previously, it was the house of the guard). This small space, little modified since 1885 , could easily become a meeting place for social agents that 
enhance the evolutionary values concerning productive cohesion (artisanal winemakers of Salto), administrative (Directorate of Culture of the Intendency), social and cultural (association of descendants of the Basque pioneers, Saltoko Euskaldunen Taldea, neighbourhood associations of the neighbourhood of Saladero, founded by Harriague, and the University itself).

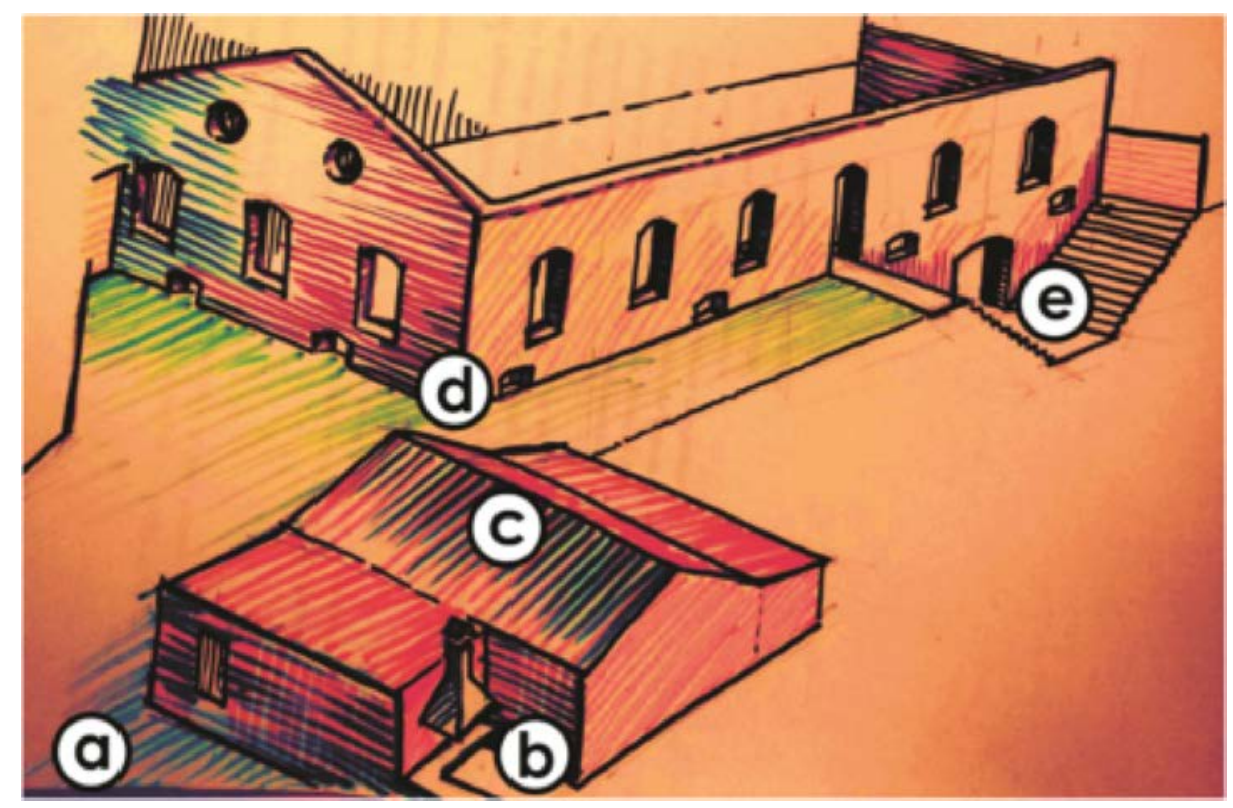

Figure 4: Schematic of the potentially usable spaces of the Harriague Winery property. (a) Outside Esplanade of reception; (b) Outside reception / rotisserie counter; (c) House of the Soil Laboratory; (d) Street/museum; (e) Entry to internal spaces; (f) Storehouse discovered for events; (g) Harriague Paschal Museum/video projections; (h) Barrels gallery.

\subsection{Intervention on the landscape}

The preliminary intervention on the landscape would be focussed on the spaces that we define as representative, symbolic, of the same. With a minimum reversible action, the Soil Laboratory is expected to become a space for cultural and commercial exchange linked to traditional wine production. In it the local producers will have their show room and place of exhibition of new products, among them those developed in joint venture with the Basque winemakers who want to participate in the project.

\subsection{Diffusion and socialization of the landscape}

The diffusion towards the outside of the features that characterize the Basque and Salta identities will be mainly carried out through musealization proposals that achieve the maximum diffusion of the work of Pascual Harriague. We intend to use only the essential resources so that this diffusion is satisfactory, and to design museographical means as simple as impressive and ingenious, without stealing prominence to the built spaces (see Fig. 5). 


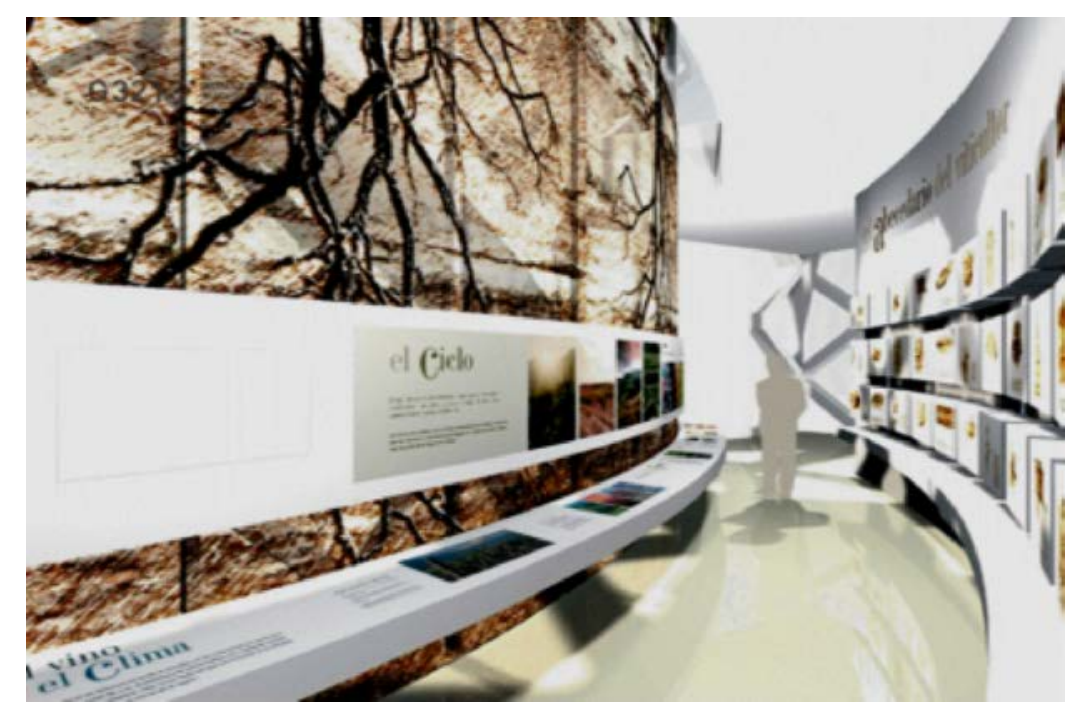

Figure 5: Museum resources designed to disseminate the winemaking process. (Source: Source: Own elaboration.)

\section{CONCLUSIONS: IMPACT AND REFLECTION OF THE PROJECT}

The old values of "production" and "industriousness/steadfastness", which gave meaning to the parameters of the modern economy, have now been replaced by a hedonistic ethic [22], [23]. This search for enjoyment and well-being comes, therefore, from inexhaustible resources, provided that they are managed (like regenerative natural resources) in a sustainable manner, recovering the reference of the physiocrats of the 18th century to the natural order and its equilibrium, understood then as constantly expanding.

The culture of knowledge must be valued not only by its "objective", "logical" or "rational" elements; also by the "subjective", "analogical" or "emotional" ones. Paraphrasing Carrillo, "to found the sustainable development of a city or region requires both rational and emotional capital; financial as relational; technological as well as cultural" [24]. Keep in mind that "it is not the accumulation of capital - growth - but its balance - the integral development - what provides identity, health, cohesion and future viability to a society and what constitutes, therefore, the true wealth of the nations" [24].

The economy should not evaluate the potential of a society, of the landscape it inhabits, of the system that works with its interrelations, in traditional terms and tangible capital, but to consider all the elements of value that are expressed in it [25].

Consequently, the culture of a community and, by extension, the landscapes where it manifests itself constitute a field for the experimentation of progress in novel fields such as that of non-commercial goods, the revision of the assumption of rationality of economic agents, the analysis of the behaviour of public institutions and the information economy.

\section{ACKNOWLEDGEMENTS}

In order to resignify the landscape of the production and marketing of Tannat wine on the banks of the Uruguay River, a research process has been started on the "fragmented heritage" that makes it up, in which two universities on both sides of the Atlantic (UDELAR and UPV/EHU) actively collaborate under the auspices of the Municipality of Salto, local cultural 
groups such as the Basque Group of Salto, the contributions of winemakers of the region and the advice of the Honorary Commission of Historic Heritage of Salto. We show our sincere thanks to all these participating agents previously mentioned for their unconditional support and to all those without whose collaboration, our work would not have been possible.

\section{REFERENCES}

[1] Council of Europe, The European Convention of Florence Convenio - Europeo del Paisaje - Ministerio de Cultura, Madrid, 2008; Ministerio de Medio Ambiente, Madrid, 2007. Article 1a, 2000.

[2] Lopo, M., Los "paisajes (culturales)" como potenciales integradores del patrimonio fragmentado; otro aporte para las clasificaciones desde una mirada territorial (nada apocalíptica). Jornadas Paisajes Culturales en Argentina, ICOMOS-Universidad Nacional de Rosario, Argentina, p. 1, 2007.

[3] Ecos del Progreso, Cuadro estadístico de los viñedos de Salto, levantado por Ecos del Progreso en el mes de diciembre de 1895. Revista Ecos del Progreso, 1895.

[4] Villaverde, P., Salto de Ayer, 3 de agosto de 2015, Online. www.saltodeayer.blogspot.com/2015/08/. Accessed on: 11 Jan. 2019.

[5] Solari, B.N., Viñedos del Departamento del Salto, Salto. El Progreso, p. 6, 1895.

[6] Castelli, W.D. \& Grasso, A., Paisaje Tannat: Cultural de viñedos y vinos en el Litoral Noroeste. Seminario de paisajes culturales UDELAR/UPC (Conpadre n.11/2012), Red Conpadre, Montevideo, Uruguay, p. 9, 2012.

[7] COTEC, Informes sobre el sistema español de innovación. Innovación en el sector del patrimonio histórico. COTEC Foundation for Technological Innovation: Madrid, p. 25 2010.

[8] Criado, F., "Hacia un modelo integrado de gestión de investigación y gestión del Patrimonio Histórico: La cadena interpretativa como propuesta". Boletín del Instituto Andaluz del Patrimonio Histórico, 16, pp. 73-78, 1996.

[9] Bertalanffy, L., Perspectivas en la Teoría General de Sistemas, Estudios Científico Filosóficos. Alianza Editorial S.A.: Madrid, 1979.

[10] Alexander, C., La Estructura del Medio Ambiente, Tusquets: Barcelona, 1971.

[11] RAE (Real Academia Española), Diccionario de la lengua española, 22nd ed., 2001.

[12] Countryside Commission, Countryside character: The character of England's natural and man-made landscape, vol. 3, 1998.

[13] Nora, P., Les Lieux de Mémoire [1984-1992], Gallimard: Paris, vol. 3 p. II, 1997.

[14] Halbwachs, M., La Mémoire Collective, Presses Universitaires de France: París, p. 106, 1950 [2nd ed., Presses Universitaires de France: Paris, 1967].

[15] Lynch, K., La Imagen de la Ciudad, Gustavo Gili: Barcelona, 1984, 1998 [MIT Press: Cambridge, 1960].

[16] Berkes, F. \& Folke, C., Linking social and ecological systems for resilience and sustainability. Linking Social and Ecological Systems: Management Practices and Social Mechanisms for Building Resilience, Cambridge University Press: Cambridge, pp. 1-26, 1998.

[17] Torres E. \& Romero, J., Gestores culturales. Entre la cultura y el patrimonio. Bulletin de l'Institut Français d'Études Andines, 34(3), pp. 277-288, 2005.

[18] De la Fuente, A., Proyecto Básico de Puesta en Valor de las Murallas Prefundacionales de Vitoria-Gasteiz, A 0030, COAVN: Vitoria-Gasteiz, 2010.

[19] Stanley, H., Udy, Jr., Estructura social: análisis structural. Enciclopedia Internacional de las Ciencias Sociales, Aguilar: Madrid, 1974. 
[20] Carrillo, F.J., Ciudades del conocimiento: el estado del arte y el espacio de posibilidades. La innovación en la sociedad del conocimiento: retos y oportunidades para los países iberoamericanos. Medellín: Colombia, pp. 28-60, 2004.

[21] De la Fuente, A., Proyecto Básico de Puesta en Valor de las Murallas Prefundacionales de Vitoria-Gasteiz, Inédito, Visado el 1 de Febrero de 2010, A 0030, Colegio Oficial de Arquitectos Vasco-Navarro: Vitoria-Gasteiz, 2010.

[22] Ruiz de Olabuénaga, J.I., Econornía y Ocio. El Mercado de la Cultura. Mercurio. Revista de Economía y Empresa, 1, pp. 11-24, 1997.

[23] Harvey, D., The Condition of Postmodernity, Basil Blackwell: Oxford, p. 9, 1989.

[24] Carrillo, F.J., ¿Qué es la Economía del Conocimiento?, Transferencia, 18(69), 2005.

[25] Sakaya, T., The Knowledge Value Revolution, Kodansha international: Tokyo, 1991. 